\title{
Social Climber and Hyperreality (Revisiting Maslow Theory in The Contemporary of Indonesia)
}

\author{
Fitri Murfianti ${ }^{1}$ and Ira Dwi Mayangsari ${ }^{2}$ \\ ${ }^{1}$ Visual Communication Design, Faculty of Art and Design, ISI Surakarta \\ ${ }^{2}$ Faculty of Communication and Business, Telkom University \\ 1 fitri@isi-ska.ac.id,2 ${ }^{2}$ radwi@telkomuniversity.ac.id
}

\begin{abstract}
Appearing luxurious on social media is imperative for some people to get attention and recognition from other netizen. This is a social disease called social climber. This study is analyzed using literature research methods, as stepping stone to understand more deeply the new symptoms in the society, which conducts a series of activities relating to the methods of collecting library data, reading, recording and processing research materials. The result of these research reveal that the existence of social media can also make someone trapped imaging, and live in hyper reality. It is easy for social climber actors to raise their social status through their uploads on social media, although by justifying all means, such as editing photos, to change their identities. In Maslow theory, this social cluster phenomenon is in the fourth stage, namely the need for esteem or self-esteem. For some people, in this era it is pivotal to get awards from others, such as social status, popular, and famous.
\end{abstract}

Keywords : Social Climber, Hyper reality, Maslow Theory

\section{INTRODUCTION}

The big wave of the digital world is unstoppable and has given birth to a new society called a networked society that carries out social interaction online through social media. The turn of these millennium is marked by rapid developments in digital technologies[1]. This technology can deliver anyone who can make good use of it but it is not uncommon to destroy someone's dignity in various ways.

Various types of social media have developed with various advantages in supporting interface such as Facebook, Instagram, Path, Twitter, Whats App, etc. This is as stated by Sherry Turkle that computer screens are said to be second self [2]. Luik, J in the Journal Communication Science, volume 3, number 1 states that social media can be considered a "home" in the virtual world, at least the development of technology so far has enabled the presence of users on social media to represent themselves (sometimes using the term virtual self, digital me, virtual me, virtual identity), but it has not yet reached the level of complete self [3]. People tend to build a cool image like in a theater, what is shown on the stage is very different from the reality behind the stage, as stated by Erving Goffman [4], a famous sociologist in the 20th century, described life as a parable of a drama performance. The situation in daily life is likened to a stage performance and human is an actor in the drama to show impressions to the audience. In line with Andrea Bornior, $\mathrm{PhD}$, who is a professor of 
psychology at Georgetown University, Washington, it is true that naturally, everyone wants to show the best side of itself to the wider world [5]. But what is unfortunate is if what is shown on social media is not real life. The sophistication of technology and the development of various applications in the digital world make a variety of abuse occurs at the personal, social and national levels. Many technological changes have dramatically affected the way we consume, present ourselves, and communicate[6].

The development of various photo editing applications, such as Adobe Photoshop Express, Adobe Photoshop Lightroom, Snapseed, Picsay, Cymera, PicsArt, etc. enabled netizens to create their best photos by providing color filters, combining multiple photos, cropping photos, brightening photos, to the most Extreme replace his identity and profile photo with someone else's photo. As written by Wood \& Smith that on social media identity becomes liquid and can change. Devices on social media allow anyone to be anyone, even can be a user who is very different from the reality, such as the exchange of gender identities, marital relationships, to profile photos [7].

Currently, netizen use social media for imaging. Many cases were presented in the media related to this matter. A new comer singer in Indonesia has shown photographs of the luxury lifestyle on his IG. But apparently, the photos were allegedly stolen from a celebrity's IG named@milesmogul, then edit the photo with his face. So it was as if he was traveling on a first-class aircraft that cost a fortune. There are some photos from other Instagram users that were also taken, ranging from the pose sitting on the plane to the parked luxury car[8].

Another case is a woman named Marieta Safitri who has become a byword in cyberspace because it is said to have cheated many people to hundreds of millions of rupiah by promising a cheap flight ticket promo through a travel agent she made named Roxy Tour Travel. Hundreds of millions of proceeds from this fraud was used to travel abroad and buy luxury goods to display on social media[9].

Some of the phenomena above show that increasingly developing technology makes it easier for people to upload and share their special moments on the internet. This can also be easily done with the help of social media platforms which can be downloaded for free. Moreover, the existence of social media can also make someone trapped in imaging.

Nowadays, appearing luxurious on social media is very important for some people to get attention and recognition from other netizen. This is a social disease called social climber. Social Climber itself is a social disease that can undermine the nation's morals. The manifestation of this disease is the feeling of wanting to be seen to appear rich wherever and whenever. As a result, everything will be done to maintain social status in society. In the concept of Maslow's Hirearki theory, there are five levels of basic needs namely physiological needs, security needs, love needs, affection and ownership, esteem needs, and self-actualization needs. In this digital age, it is interesting to see the social climber's life as a hyper reality and where the position of social climbers who consider luxury and hit as a necessity in Maslow's hierarchy of needs.

\section{METHOD}

This study is analyzed using literature research methods, as part of preliminary research or stepping stone to understand more deeply the new symptoms that are developing in the field or society or social phenomena that are currently taking place based on relevant theories. Literature reviews also provide a solid background for a research paper's investigation. Comprehensive knowledge of the literature of the field is essential to most research papers [10]. A good literature review doesn't just summarize sources, it aims to analyze, interpret and 
critically evaluate the literature, Synthesize sources to highlight patterns, themes, conflicts, and gaps, Show the state of current knowledge in relation to a central research question or hypothesis [11]

\section{RESULT AND DISCUSSION}

\subsection{Revisiting the Concept of Maslow's Hierarchy of Needs Theory}

The theory put forward by Maslow is a theory of the hierarchy of basic human needs as a foothold of other scientific developments related to the fulfillment of basic human needs. Meeting basic needs is divided into a certain level that prioritizes human needs from the most basic. Humans are psychologically motivated by a series of hierarchical needs, starting with the most essential first[12].

According to Maslow, the satisfaction of needs is driven by the motivational forces of deficiency growth and motivation for growth. A motivation for deficiencies is an effort made by humans to meet the deficiencies experienced. While development motivation is a motivation that grows from the basis of the human self to achieve a goal of self-based on its capacity to grow and develop. The capacity or ability of each person is different and is innate.

In this theory, humans are positioned as creatures that are weak and continue to develop, have the potential for self-achievement and are influenced by the environment to be able to grow tall, straight, and beautiful. Maslow's theory of needs hierarchy has five levels of basic needs namely physiological needs, security needs, love needs, affection and ownership, esteem needs, and self-actualization needs. Maslow's hierarchy of needs is arranged in a triangle where the base has a larger area and cones upwards. The lowest level is the most basic needs and continues at the second, third, and so on until the highest level at the top of the pyramid. Following is Maslow's hierarchy of needs.

\subsubsection{Physiological Needs}

Physiological needs are related to biological body needs. Physiological needs include food, water, oxygen, and normal body temperature. These physiological needs are the basic needs that support human life. Physiological needs are the first basic needs that humans will seek to achieve life satisfaction. If one of these physiological needs is not obtained, it will interfere with the fulfillment of further basic needs.

\subsubsection{Security Needs}

The second basic need is security. When the first basic needs are met, the need for security becomes active. This need for more security in children because their awareness of self-limitation is still lacking. So there is a need for others to provide security for them. In adults, security needs are more in an emergency, disaster, or organizational failure in social structures. The existence of an unpleasant situation makes adults look for a place or people who can meet their security needs.

\subsubsection{Love, Ownership Needs}

When physiological and security needs are met, the next level is the need for love, affection, and ownership. Maslow states that people look for ways to overcome feelings of loneliness or loneliness. Humans need love, affection, and belonging. Not only being loved but also loving, ie giving the same needs to others will also meet their own basic needs. There are two types of love namely Deficiency or also called D-Love and being or B-Love. The need for love due to lack of it includes D-Love and people who love something they don't have, such as marriage, special relationships, self-esteem. D-Love is self-focused love, which is more concerned with how to get rather than how to give. Whereas B-Love is an assessment of someone as is without any desire to use that person. Love that does not intend to have, love 
that gives support to others to develop, love that gives a positive impact, acceptance and a sense of being loved.

\subsubsection{Esteem Needs}

Esteem needs can include self-esteem needs or appreciation from others. When the needs of the third level are met then the need for esteem will emerge. Humans need to be respected by others, trusted by others, and self-stable. When this need has been reached, the level of confidence of a person will also increase and have high self-esteem. This will affect the social role and activities in social interaction. If these esteem needs cannot be achieved, then people become depressed, insecure, low self-esteem, and feel worthless or useful.

The form of self-esteem is divided into two types, Firstly, Self-respect, such as achievement, self-confidence, independence, freedom, strength, ability, and competence. Secondly, get awards from others, such as status, popular, famous, dominance, appreciation for hard work, prestige, awards in the form of praise from others, and good judgment from others.

\subsubsection{Self Actualization Needs}

The next requirement that needs to be met after the other four needs are met is the need for self-actualization. Self-actualization is a tangible form that reflects one's desires for himself. Maslow describes self-actualization as a person's need to achieve what he wants to do. For example, a musician must play music, an artist must paint, a dancer must practice motion and others. The form of self-actualization is not easy to achieve because it needs support from various parties. If this need cannot be achieved, it will cause anxiety, uneasy, tense, feel his self-esteem is falling. If the need for love is lacking, unloved, hungry, insecure, then it will be easy to know what makes him nervous. But the lack of self-actualization needs is difficult to clearly understand what someone wants.

\subsection{Social Climber on Social Media as a Hyper reality}

Technological development is always directly proportional to its impact on society. Neither the development of the internet raises a variety of phenomena on social media. Nowadays social media is a part of human life, many people spend their time playing on social media. Social media can also be a place to store HD stories, where you can upload anything and become anyone, including this social climber. Social Climber is a term used for people who seek social recognition that is higher than the actual condition or status. The term 'Social Climber' reappears along with the height of the news about the phenomenon of showing luxury in social media. Like when hanging out at a famous restaurant or cafe, sometimes people have to post it first on their social media accounts. Even when someone has just bought expensive or branded goods. You could say some social media also contributed to shaping the social mentality of the Indonesian nation. It is not uncommon for this social climber to be able to use other people to achieve their desires.

Even though they have as much and as luxurious goods, their lives are not necessarily as happy as others think. The most important thing for a social climber is the status that would be considered high by others. Finally, it was also imitated by ordinary people, by trying to live the life of a hedonist by often showing off what they have.

Almost everyone tends to want to have a high social status. But the difference is, people who contracted this social climber did not appreciate the process. They prefer to use the instant, which is important fast famous / hits. The question is, who can be infected? Maybe if in the past only teenagers were often affected by this disease. But now the data is no longer valid. Because social media users are already from various ages. Not only teenagers but now parents also show off to post hedonist activities such as holidays, buy luxury goods and even do charity (boombastis.com). This is a personal right, but if done continuously it will form a 
mental social status that always wants to be recognized. So the conclusion can all be infected with this social disease.

To read this phenomenon, it can be started by examining three interrelated terms; namely simulation, simulacra, and hyper reality. It should be noted that the three are inseparable from each other. To achieve hyper reality, there should be a form of simulacra presented by the media so that the exposed audience perceives the representation as real [13].

The first term is simulation means imitation. The point is that artificial reality still refers to real reality. Media no longer displays reality but has become a reality in itself, even what is in the media is more real than reality itself. The reality of the media is the result of a simulation process, where the representation in the media has been produced and reproduced by the media itself into its reality that sometimes what is represented is different or even contradictory. How the simulation occurred explained Baudrillard with what happened in an industrial society that at this time production no longer produces a multiplication of reality, but has become a mass production of identical reality which sometimes has no similarity with what is represented.

Whereas the second term, Simulacra, Baudrillard interprets it with mock realities that no longer refer to real reality. The substance of the initial reality has disappeared, the reality produced by technology has become a completely new reality. This is what Umberto Eco described as hyperreality (1987) in the book 'Traveling in the Realm of Hyperreality'. For Baudrillard, himself is creation through models of something tangible without origin or reality. For Piliang, it is an effect, condition, or material or space experience that results from the simulation process. It may form a duplication of the world of nostalgia and fantasy [14]. Here, this reality is not yet completely said to be a truly real reality. Because good/ interactive relationships have not yet occurred. Or it can be called semi-reality.

The term simulacra are used by Baudrillard to describe how reality in the media is an illusion, not a reflection of reality, a sign that no longer represents an initial sign, but has become a new sign. Baudrillard called it "a copy of a copy with no original". On social media, the interactions that occur are simulations and sometimes are different. For example, social media allow anyone to be anyone, can even be a user who is very different from reality, such as the exchange of gender identity, the marriage relationship, to the profile photo [15].

The third is Hyperreality. This is what is called a real reality, even above the real one, which will replace the previous real reality. That is, hyper reality is a deconstruction of the previous real reality because this reality will be very different from before. Or in his book Yasraf Amir Pilliang, entitled The Folded World, Hyper reality (Hyper-reality) is explained by Baudrillard as, a state of collapse of reality because it has been taken over by virtual engineering that is considered more real than reality itself, so the difference between the two becomes blurred. In hyper reality, the "original" version of an object has no real significance since it belongs to a different realm and therefore loses its referential value [16]. While the difference between the simulacra phase and the hyper reality phase lies in its interactive characteristics. Namely, things that could only be done in real reality, have now been replaced in virtual reality, such as interacting, economic transactions, meetings, learning and so on. Even more effective and efficient are these new methods. While in the simulation phase and the simulacra phase, things like this haven't happened yet. Hyper reality, the virtual reality in which people live, structured by information and technology, is sustained on an amalgamation of elements which were previously separate, such as production and consumption, and by a dissipation of the system of values based on the illusion that economy and society have a defined meaning or any meaning at all[17].

On the other hand, when an individual interacts through an interface, basically he is 
conducting a self-transaction by interpreting other individuals. From the name, display picture, self status, daily status, or meme that the individual uploads on his social media wall regularly. What he interprets and the meaning of individual accounts on social media is the appearance of pseudo-reality or hyperreality. Because basically, the individual accounts are self-representations of the account owner, and can even be in the form of simulations that are not based on actual reality. A post-reality. The reality that has no reference at all in reality. This is a simulation in the world of social media. The process of individual interaction with other individuals on social media will create an affirmation of status. Who is he, from which social stratification he is? He slowly establishes the status which ultimately leads him to a certain identity. In the cyber world. The status he gets from what he displays and uploads every day is a form of identity in the world of simulation. Because basically, the interaction that is done does not refer to the real reality.

In the book Social Media: Perspectives on Communication, Culture, and Sociotechnology, Nasrullah writes that Baudrillard expressed the simulation idea that awareness of the real in the minds of the public is diminishing and replaced with pseudo-reality [18]. This condition is caused by the images presented by the media continuously. The audience seems to be unable to distinguish between what is real and what is on the screen. The audience seems to be between reality and illusion because the signs in the media seem to have been cut off from reality.

In addition, simulacra concerning hyper reality occurs because of a ceasefire that must be done by some audiences who have been psychologically exposed by media technology. For example, with the facilities "follow", "like", "love", and so on, the audience is competing to make the best simulation to portray themselves or to create an image that is liked by the public, where it has been made far from the real character. As if it is personal pride when someone has the most followers or gets the most likes. This facility not only affects one's psychic but also affects a person's emotional quality.

\subsection{Social Climber in Maslow's Hierarchy of Needs}

In communication science, "social climber" is something that can be tried to get a stronger position in participation both individually and in groups. This was revealed in his book Communication Mozaich Social climber is the process of trying to increase personal status in a group by waiting for the high-status member [19]. Through this status, they try to improve social judgment about themself. Sociogeneous motives are striking in the behavior of social climbers, acting on social push. Their anxiety will increase when unable to meet social expectations, they form social sanctions subjectively. Social climbers will be very sensitive to criticism and worship the fictional appreciation of the social environment [20]. The social hierarchy motivates individuals to pursue social status, forming competition among members of a social group as a social challenge that needs to be met [21].

\section{CONCLUSION}

The development of internet technology has made it easier for netizen to upload and share their special moments through social media platforms, including the feeling of wanting to look luxurious wherever and whenever they are. The existence of social media can also make someone trapped imaging, and live in hyper reality. It is very easy for social climber actors to raise their social status through their uploads on social media, although by justifying all means, such as editing photos, to change their identities

Social Climber itself is a social disease that can undermine national morale where luxury and hits are necessity. This social cluster phenomenon is in the fourth stage, namely the need 
for esteem or self-esteem. When the needs have been met to the third stage, namely love, affection, and ownership, then they need domination, appreciation for hard work, prestige, appreciation in the form of praise from others, and good judgment from others. For some people, in this era it is paramount to get awards from others, such as social status, popular, and famous

\section{REFERENCES}

[1] Y. Yoo, K. J. Lyytinen, R. J. Boland, and N. Berente, "The Next Wave of Digital Innovation: Opportunities and Challenges: A Report on the Research Workshop 'Digital Challenges in Innovation Research,", SSRN Electron. J., Jan. 2012.

[2] D. Holmes, Teori Komunikasi. Jakarta: Pustaka Pelajar, 2012.

[3] J. E. Luik, "Media Sosial dan Presentasi Diri - Scientific Repository," Asosiasi Pendidikan Tinggi Ilmu Komunikasi,. [Online]. Available: http://repository.petra.ac.id/15386/. [Accessed: 08-Nov-2019].

[4] Morissan, Teori Komunikasi : Individu hingga Massa. Jakarta: Kencana, 2013.

[5] "Waspadai Perangkap 5 Potret Kehidupan Palsu di Media Sosial Ini!" [Online]. Available: https://www.idntimes.com/life/inspiration/sertieun-1/waspadai-perangkap-potret-kehidupan-pal su-media-sosial-c1c2. [Accessed: 12-Nov-2019].

[6] R. W. Belk, "Extended Self in a Digital World: Table 1.," J. Consum. Res., vol. 40, no. 3, pp. 477-500, Oct. 2013.

[7] M. J. Wood, Andrew F. Smith, Online Communication Linking Technology, Identity, and Cult, Second Edi. London: Lawrence Erlbaum Associates, 2005.

[8] "Demi Nampak Hidup Mewah, Adriansyah Martin Diduga Curi dan Edit Foto di IG KapanLagi.com." [Online]. Available: https://www.kapanlagi.com/showbiz/selebriti/demi-nampak-hidup-mewah-adriansyah-martin-di duga-curi-foto-dan-edit-foto-di-ig-baa0e3.html. [Accessed: 11-Nov-2019].

[9] "Social Climber Makin Menjamur. Si Miskin yang Pengen Kekinian.” [Online]. Available: https://www.selipan.com/story/social-climber-makin-menjamur-si-miskin-yang-pengen-kekinia n/. [Accessed: 11-Nov-2019].

[10] "Literature Reviews - The Writing Center." [Online]. Available: https://writingcenter.unc.edu/tips-and-tools/literature-reviews/. [Accessed: 10-Nov-2019].

[11] "How to Write a Literature Review | A Step-by-Step Guide." [Online]. Available: https://www.scribbr.com/dissertation/literature-review/. [Accessed: 10-Nov-2019].

[12] S. Stoyanov, A theory of human motivation. Taylor and Francis, 2017.

[13] P. S. . Cempaka and Haryatmoko, "Hyperreality Among Defense of the Ancients 2's Players," J. Komun. Indones., vol. VII, no. 3, 2018.

[14] Y. A. Piliang, Hipersemiotika: Tafsir Cultural Studies Atas Matinya Makna. Yogyakarta: Jalasutra, 2003.

[15] J. Baudrillard, Masyarakat Konsumsi. Yogyakarta: Kreasi Wacana, 2009.

[16] R. W. Wolny, "Hyperreality and Simulacrum: Jean Baudrillard and European Postmodernism," Eur. J. Interdiscip. Stud., vol. 8, no. 1, p. 76, 2017.

[17] T.-C. Hermano Roberto, "BAUDRILLARD: WORK AND HYPERREALITY," RAE-eletrônica, v. 9, n. 1, Art. 7, jan./jun. 2010.

[18] R. Nasrullah, Media Sosial (Perspektif Komunikasi, Budaya, dan Sosioteknologi). Jakarta: Simbiosa Rekatama Media, 2015.

[19] J. T. Wood, Introduction to the Field of Communication, 5th Editio. USA: Thomson Wadsworth, 2006.

[20] A. Edward, "The International Cocktail Bitch: Negative Affect and Critical Punishment in the Social-Climbing Fiction of Edith Wharton, Anita Loos, and Nella Larsen," UMI Disertation Publ., no. May, 2012.

[21] N. A. Hays, "Social Climbing: A Contextual Approach to Understanding the Effects of Social Hierarchy on Individual Cognition and Behavior," p. 63, 2017. 